\title{
MARIÁTEGUI Y SU TIEMPO. LA PROPUESTA ANTROPOLÓGICA DE UN MARXISTA HETERODOXO
}

\section{MARIATEGUI AND HIS TIME. THE ANTHROPOLOGICAL PROPOSAL OF A HETERODOX MARXIST}

\section{Paula Jimena Sosa}

CONICET-Universidad Nacional de Tucumán- Centro de Estudios Modernos jimenasosa89@gmail.com

Palabras claves: Mariátegui- Antropología - Espiritualismo - Marxismo - Mito.

Keywords: Mariátegui- anthropology- Spiritualism- Marxism- Myth.

Resumen: Las reflexiones de Mariátegui en torno a las condiciones sociales de su tiempo le permiten crear un estilo propio que traspone las herramientas teóricas del marxismo y el vitalismo a la realidad peruana. Este trabajo busca en primer lugar, presentar el clima intelectual en el que se encuentra Mariátegui, con el fin de evidenciar las peculiaridades de su pensamiento, en un contexto de gran movilización intelectual; en segundo término, dimensionar el lugar que tuvo el concepto de "mito" de Sorel en un contexto de idealismo "arielista" en Latinoamérica y, por último, mostrar la propuesta antropológica que emerge de sus lecturas de Bergson y Nietzsche.

Abstract: Mariátegui's reflections on the social conditions of his time allow him to create his own style that transposes the theoretical tools of Marxism and vitalism to the Peruvian reality. This work seeks, first of all, to present the intellectual climate in which Mariátegui finds himself in order to highlight the peculiarities of his thought in a context of great intellectual mobilization; Secondly, to assess the place of Sorel's concept of "myth" in a context of "arielist" idealism in Latin America and, finally, to show the anthropological proposal that emerges from his reading of Bergson and Nietzsche.

\section{Introducción}

El presente trabajo intenta abordar las raíces teóricas de las que se nutre José Carlos Mariátegui a la hora de elaborar su propia concepción del marxismo para el caso peruano. En este sentido, coincidimos con las lecturas de la historiografía intelectual de la izquierda peruana propuesta por Oscar Terán, Robert Paris y José Aricó quienes se- 
ñalan la capacidad creativa de Mariátegui a la hora de pensar un marxismo heterodoxo, en un contexto de gran complejidad a nivel global. De allí que Aricó lo llame, "rara avis que ante una etapa difícil y de cristalización dogmática de la historia del movimiento obrero y socialista mundial se esforzaron por establecer una relación inédita y original con la realidad". 1

Por consiguiente, analizaremos primeramente el ambiente intelectual del Perú de la década de 1910 y 1920, poniendo énfasis en su carácter de reacción contra el positivismo determinista. En segundo lugar, ubicaremos el pensamiento del filósofo peruano en la nueva generación peruana, que articula la transición del modernismo al vanguardismo. En este sentido, se evidenciarán los elementos tomados del ideal arielista y el lugar que adquirió en este momento el concepto de mito, entendido como elemento central de una estrategia de vinculación entre marxismo y el idealismo a la hora de radicalizar el campo intelectual. En este momento se intentará evidenciar si la impronta soreliana no funciona como un medio para la construcción de un perfil antropológico cargado de elementos bergsonianos y nietzscheanos.

Esperamos contribuir con nuestro trabajo al esclarecimiento del clima de ideas de Mariategui por medio de los aportes de Pablo Quintanilla, Fernanda Beigel, Oscar Terán y José Aricó entre otros; en segundo término, comprender la mediación que tiene Sorel en la configuración mariategiana de mito político, como herramienta que habilita la construcción de un perfil antropológico novedoso. Para esta última

1. Aricó, J. (1980) "Prólogo", Mariátegui y los orígenes del marxismo latinoamericano, 1980, p. 13. etapa, nos valemos de los avances de María José Cisneros y Alfonso Ibáñez en torno a la recepción de ideas de Friedrich Nietzsche, George Sorel, Henri Bergson y Karl Marx. La hipótesis que rige nuestra investigación es que esta polifonía ${ }^{2}$ funciona como herramienta para presentar un modelo antropológico innovador destinado a afrontar los problemas que circundan la realidad peruana de su tiempo.

\section{La situación intelectual en el momento de surgimiento de la obra de Mariátegui}

A fines del siglo XIX y comienzos del XX la filosofía peruana se desplaza desde corrientes positivistas hacia el espiritualismo. De acuerdo con Pablo Quintani$11 a^{3}$, se opera un movimiento que va de una concepción representacionalista del conocimiento, asociada a un monismo ontológico y metodológico, hacia una concepción en la cual no hay un solo conocimiento, sino una superposición de varios. La primera etapa se asocia a la metáfora del espejo, con lo cual la filosofía de Perú es entendida como reflejo del debate filosófico europeo. La segunda etapa, en cambio, trata de expresar una transición hacia una autocomprensión distinta pues no es un reflejo, sino una combinación de elementos de la filosofía europea con

2. El concepto de polifonía lo tomamos desde la perspectiva de Bajtin en La cultura popular en la Edad Media y en el Renacimiento: el contexto de François Rabelais (1941), es decir, atendiendo a la diversidad de voces que rodean la obra de Mariátegui.

3. Quintanilla, P. (2004) “Del espejo al caleidoscopio: aparición y desarrollo de la filosofía en Perú", Areté. Revista de Filosofía, vol. 16. pp. 43-79. 
elementos creativos y reflexiones propias vinculadas a la imagen del caleidoscopio.

Las razones que pueden explicar la transformación de la praxis intelectual se debe entre otras a una serie de procesos de escala nacional e internacional. Por un lado, la Primera Guerra Mundial desata un estado de dudas en torno al mundo europeo como modelo cultural y, por otra parte, un momento de modernización económica de Perú acompañada de una creciente movilización obrera y estudiantil. Estas transformaciones sin duda impactan en el ambiente intelectual. Las reformas educativas tienden a incluir las clases en ascenso permitiendo un mayor acceso a la educación primaria, secundaria y universitaria y ponen en la agenda intelectual la temática indigenista. En este contexto, se produce la emergencia de grupos intelectuales que, como sostiene Terán ${ }^{4}$, desde la marginalidad buscan fisurar la concepción tradicionalista de la nación peruana.

Ahora bien, a mediados del siglo XIX, el positivismo europeo presenta una concepción del conocimiento que domina el terreno filosófico sosteniendo que conocer es reflejar los hechos del mundo. Este enfoque tiene eco en los filósofos e intelectuales positivistas peruanos de la segunda mitad del siglo XIX, como Javier Prado (1871-1921), Alejandro Deústua (1849-1945), Jorge Polar Vargas (18561932), Manuel González Prada (18481918), Mariano Cornejo (1866-1942), Manuel Vicente Villarán (1873-1918) y Mariano Ibérico (1892-1974), entre otros. Así, entre los inspiradores del positivismo peruano encontramos en un primer momento, la recepción de ideas de Auguste Comte, y luego las de Herbert Spencer,

4. Véase Terán, O. (2008) “Amauta: Vanguardia y Revolución”, Prismas, vol. 12, pp. 173-198.
Émile Boutroux, Hippolyte Taine y JeanMarie Guyau.

Posteriormente, aparecen los cuestionamientos provenientes del espiritualismo francés, con impronta hegeliana, a la concepción representacionalista del conocimiento y la idea de que hay un solo tipo de conocimiento basado en datos empíricos y de carácter utilitario. En este sentido, se abre un nuevo período en el clima intelectual de la época orientado a las nuevas formas de pluralismo. Estas concepciones antirepresentacionalistas, que admiten la posibilidad de varios conceptos diferentes de conocimiento (que incluso podrían no ser formas de representación, como la intuición artística o la psicológica), no fueron desarrolladas plenamente pero tuvieron importancia a la hora de desplegarse la crítica al representacionismo.

En Perú el rechazo al positivismo se inicia con autores que habían formado parte de generaciones positivistas como Javier Prado, Jorge Polar, Alejandro Deustua y Mariano Ibérico. El desplazamiento del positivismo al espiritualismo no logra consolidar a esta última corriente como empresa filosófica. Las razones de esto fueron múltiples, pero entre ellas, Quintanilla destaca en primer lugar, la imposibilidad de llegar a un significado conciliado sobre qué se entendía por espiritualismo; en segundo término, porque las mismas tesis espiritualistas eran entendidas confusamente; en tercer lugar, porque con frecuencia este tipo de espiritualismo conservaba elementos positivistas, sobre todo en cuanto a lo que se entendía por conocimiento. En cuarto lugar, porque el marxismo, de principios del siglo XX, también reacciona contra el espiritualismo.

En cuanto al marxismo en Perú, es posible pensar que presenta varios matices. Víc- 
tor Raúl Haya de la Torre y Manuel González Prada adhieren al marxismo bajo la configuración de la III Internacional, que permanece atado a una visión etapista del desarrollo económico. Como contrapartida de esta recepción se encuentra José Carlos Mariátegui quien, en el panorama filosófico peruano, presenta desde nuestra perspectiva la máxima expresión del abandono de la metáfora del espejo efectuando una lectura de Marx con características propias. El gesto de Mariátegui puede ser entendido como una búsqueda de provincializar ${ }^{5}$, tal como lo entiende Dipesh Chakrabarty, a Marx de acuerdo con las condiciones de la realidad peruana. En este sentido, el sujeto político no es el proletariado sino el indio.

Cabe destacar que, en el contexto peruano, ya Mariano Ibérico y Rodríguez lee con categorías novedosas a los espiritualistas cuando la interpretación de Mariátegui del marxismo empieza a consolidar un movimiento intelectual que se conceptualiza bajo la imagen del caleidoscopio. No obstante, hay elementos positivistas contenidos en la recepción de Marx en Perú, principalmente en torno al concepto de conocimiento pero también en el monismo epistemológico, ontológico y un matizado determinismo histórico.

Fernada Beigel ha señalado el impacto que tiene la obra de Mariátegui en las redes intelectuales internacionales desde la segunda mitad de la década de $1920^{6}$. Estas redes se consolidan no solo por su viaje a los centros culturales europeos,

5. Véase Chakrabarty, D. (2008) Al margen de Europa. Pensamiento poscolonial y diferencia histórica, Barcelona, Tusquets.

6. Véase Beigel, F. (2005) "La circulación de ideas La circulación internacional de las ideas de José Carlos Mariátegui”, Prismas, Revista de historia intelectual, $\mathrm{n}^{\circ}$ 9, pp. 71-87. que organizan su compleja trayectoria intelectual, sino también por sus proyectos editoriales, que alcanzan gran difusión en diarios, semanarios y periódicos latinoamericanos. Desde luego la circulación de su teoría política se encuentra plasmada fundamentalmente en la revista Amauta, impulsada por el autor peruano, que reconfigura el debate en torno al pensamiento marxista desde una perspectiva latinoamericana.

\section{La trayectoria de Carlos Mariátegui}

Sin duda la trayectoria de Mariátegui pone de relieve a un intelectual polifascetico comprometido no solo con la dimensión política de su país, expresada en sus crónicas de política nacional e internacional, sino también en su dimensión de crítico literario y de analista histórico y sociológico. Como lo señala Patricia D’Allemand7, estas facetas solo escasas veces son comprendidas de modo integral. En general sus intérpretes, sobre todo a partir de la década de 1960, recortan el corpus mariateguiano poniendo el acento en el pensador político, es decir, el escritor que analiza la realidad peruana en función de la geografía política internacional o bien el activista, esto es, el cronista de su tiempo, el marxista. Coincidimos con D’Allemand en que estos enfoques, incluso el que reivindica solo la dimensión indigenista del autor, efectúan una simplificación importante de su obra reduciendo su corpus crítico y alentando interpretaciones distorsionadas de su producción intelec-

7. Véase D' Allemand, P (2016) “Todo lo humano es nuestro: una nueva mirada al legado de José Carlos Mariátegui", en Cuadernos le literatura, vol. XX, n 40 , pp. 537-559. 
tual. Esta última, cuenta con dos obras publicadas en vida Siete ensayos sobre la realidad peruana y La escena contemporánea (1925) y dos publicaciones póstumas de El alma matinal y otras estaciones del hombre de hoy (1950) y Defensa del marxismo (1955), además de proyecto editorial colectivo planteado en la revistas antes mencionada, Amauta, deben ser leídas integralmente como parte de un proyecto multifacético.

En este sentido, podemos rescatar la idea de algunos de sus importantes comentaristas $^{8}$ según la cual, en la obra de Mariátegui gravita una perspectiva crítica en torno al complejo mundo en que le toca vivir y una línea teórica, a través de la cual intenta alentar la imaginación política de los tiempos venideros. Para comprender dicha perspectiva crítica resulta necesario un anclaje, a grandes rasgos, en elementos de su biografía. De allí que Flores Galindo expresa,

La respuesta de Mariátegui fue encontrando al problema en el transcurso de su vida, pero especialmente entre 1923, fecha de su regreso de Europa, y 1930, se fue generando al compás de las polémicas debates donde intervino y en contacto directo con la praxis política. No se elaboró pacientemente en un escritorio, sino al interior de la vida misma, en la lucha y el conflicto, día a día. Por eso no podemos encontrar un texto, una cita, donde esté meridianamente clara la solución: hay que buscarla por el contrario

8. Véase Aricó, J. Mariátegui y los orígenes, Becker, M. Mariategui and Latin American Marxist theory, Becker, M. Mariategui, the Comintern, Löwy, Michael y Ortega Breña, M. "Communism and Religion, Mariátegui's revolutionary mysticism", Quijano, A. Introducción a Mariátegui, Terán, O. Latinoamérica, discutir Mariátegui, Flores Galindo, A. La agonía de Mariátegui. tanto en la vida de Mariátegui como en los acontecimientos que la rodean. ${ }^{9}$

Entre los trabajos que mejor resuelven la relación entre la obra intelectual de Mariátegui, su trayectoria intelectual y su contexto histórico cabe destacar los aportes de Aníbal Quijano en Reencuentro y debate. Introducción a Mariátegui (1981), Alberto Flores Galindo La agonía de Mariátegui (1980), Beigel El itinerario y la brújula. El vanguardismo estético político de Carlos Mariátegui (2003) y La epopeya de una generación (2006) y Horacio Tarcus con su obra, Mariátegui en Argentina: Las políticas culturales de Samuel Glusberg (2002), entre otros.

Ahora bien, Mariátegui proviene de un clan familiar humilde del sureste de Perú. Tempranamente se muda a una ciudad de la costa central del país donde pasa su infancia. En este período sufre un accidente por el cual pierde la movilidad de su pierna izquierda; dificultad que lo aleja de la escolaridad tradicional y desencadena el primer período de sus lecturas autodidactas. Esta condición de autodidacta no es abandona excepto en escasas ocasiones. Como el mismo se define,

Me olvidaba: soy un autodidacta. Me matriculé una vez en letras en Lima, pero con el solo interés de seguir el curso de latín de un agustino erudito. Y en Europa frecuenté algunos cursos libremente, pero sin decidirme nunca a perder mi carácter extra-universitario y tal vez, si hasta anti-universitario. ${ }^{10}$

9. Flores Galindo, A. (1980) La agonía de Mariátegui. La polémica con la Komintern, Lima, Centro de estudios y promoción del desarrollo, p. 11. 10. De la carta de fecha 10 de enero de 1927 , enviada por José Carlos Mariátegui al escritor Enrique Espinoza (Samuel Glusberg), director de la revista La Vida Literaria, editada en Buenos Aires. Se publicó la carta en su número del mes de mayo de 1930, en homenaje al recién falleci- 
Aunque alejado del mundo académico, durante su juventud participa en diferentes diarios, semanarios y periódicos locales como La Prensa y otros como Mundo Limeño, Lulú, El Turf, Vesperal y Alma Latina donde escribe cuentos, crónicas periodísticas, poemas y dos obras teatrales que no son bien recibidas por la crítica bajo el seudónimo de Jean Chroniqueur. Posteriormente, participa en El tiempo y La razón, desde donde patrocina la reforma universitaria y apoya la huelga obrera. Esta publicación genera una polémica tal que el gobierno de Leguía promociona su traslado a Europa como estrategia política para cerrar el periódico.

Su viaje a Europa entre 1919 y 1923 lo lleva a residir más de dos años en Italia, donde contrae matrimonio. También viaja a Francia, Alemania, Austria y otros países, en los cuales establece relaciones con diferentes intelectuales y políticos. Entre ellos la red de contactos que traza con Henri Barbusse y el grupo Clarté, su asistencia al Congreso Socialista de Livorno, los vínculos estrechados en Italia con Anton Giulio Bragaglia a cargo de Index y Pettoruti, quien conecta a Mariátegui con publicaciones como Le arti plastiche e II Dramma y, por fin, en Alemania conectándose con la revista Der Sturn dirigida por Herwarth Walden. Paralelamente, su trayectoria intelectual por Europa le permite construir lazos de solidaridad con algunos peruanos para la acción socialista como, por ejemplo, el poeta Cesar Vallejo. En este sentido, el Amauta expresa,

El Perú no es solo Lima; en el Perú hay como en otros países, ortos y tramontos suntuosos, cielos azules, nieves cándidas, etc. pero Lima da el ejemplo e impone las

do Mariátegui. Disponible en: https://www.marxists.org/espanol/mariateg/1927/ene/10.htm modas. Su irradiación sobre la vida espiritual de las provincias es inmensa y constante. Solo los temperamentos fuertes -Cesar Vallejo, cesar Rodríguez, etc.- saben resistir a su influencia mórbida. ${ }^{11}$

Sus artículos de esa época señalan esta orientación socialista, pero también su vinculación con la red editora europea fundamentalmente con L'Ordine Nuovo y La Revoluzione Liberale llevada adelante por el gestor cultural Piero Gobetti.

Durante su regreso a Perú, en 1923, el pensador peruano brinda reportajes, conferencias, como "La historia y la crisis mundial" y "El proletariado y la crisis mundial" para la Universidad Popular, creada por la Federación de Estudiantes, publica artículos, etc. En esta etapa aborda la situación europea e inicia su trabajo de investigación de la realidad nacional, siguiendo, como él mismo sostiene, el método marxista. Asimismo, asume la dirección de la revista Claridad otorgándole un nuevo perfil, que busca como interlocutor no el sector universitario, como lo propone su antiguo director Haya de la Torre, sino destinado a obreros e intelectuales.

En 1924 Mariátegui pierde una pierna quedando en una situación de gran vulnerabilidad física. Esta dificultad, como tampoco la presentada en su infancia, no lo lleva a una vida tranquila y reposada sino al recomenzar de nuevas instancias de praxis política por medio de sus proyectos editoriales. En este sentido, es como si sus condicionamientos hubiesen impulsado sus nuevas búsquedas ya que ese mismo año dirige la revista Claridad, crea la editorial obrera Claridad y luego la editorial Minerva en 1925. En este sentido expresa,

11. Mariátegui, J. (1970) Peruanicemos el Perú, Lima, Amauta, p. 16. 
Pero ni mi pobreza ni mi inquietud espiritual me lo consienten. No he publicado más libros que el que Ud. conoce. Tengo listos dos y en proyecto otros dos. He aquí mi vida en pocas palabras. No creo que valga la pena hacerla notoria; pero no puedo rehusarle los datos que Ud. me pide. ${ }^{12}$

Posteriormente aparecen dos grandes empresas editoriales de Mariátegui, es decir, la Sociedad Editora Amauta y el periódico Labor que plasma la ruptura del pensador peruano con el Alianza Popular Revolucionaria Americana (APRA) y su vinculación al nuevo Partido Socialista Peruano. Estos órganos de difusión pueden entenderse, como sostiene Beigel, como la búsqueda de estimular la comunicación en América Latina reconociendo los procesos de autonomía que se producen en el campo intelectual peruano e impulsando una serie de principios éticos, periodísticos y artísticos, por medio de una estrategia política antioligárquica y anticoIonialista.

Por lo tanto, es posible pensar a Mariátegui como un intelectual comprometido con la realidad nacional de su tiempo, donde sus lecturas se encuentran al servicio de la praxis política. De allí que las obras que recepcionan no pueden entenderse como mera traslación forzada de conceptos, que como señala Bourdieu ${ }^{13}$ genera constantemente malentendidos, sino por el contrario, como recepción creativa y crítica que atiende a las pecu-

12. Carta de Mariátegui a Samuel Glusberg del 10 de enero de 1927, Archivo Mariátegui. También puede encontrarse en La vida literaria (1930) en homenaje por el fallecimiento del escritor peruano.

13. Véase Bourdieu, P. (2002) "Las condiciones sociales de la circulación internacional de las ideas", Actas de la investigación en ciencias sociales, vol. 145, pp.3-8. liaridades de un contexto político, social y económico periférico. En lo sucesivo analizamos el impacto de uno de los aportes más novedosos a la cultura marxista del siglo XX, es decir, su elemento vitalista, espiritualista y religioso, presente sobre todo en la recepción de Geoge Sorel, Henri Bergson y Friedrich Nietzsche.

\section{La transición del ideal arielista al mito político soreliano}

De acuerdo con numerosas exégesis El Ariel, del uruguayo Enrique Rodó, abre un período en la literatura y ensayística latinoamericana que estructura un debate filosófico con relación al nacionalismo latinoamericanista como ideología revolucionaria. La presencia de dicho ensayo impulsa con fuerza la reacción antipositivista, ya que antepone principios estéticos sobre elementos pragmáticos o cientificistas. De modo que, el discurso artístico comienza a imponerse sobre el científico. Sin embargo, fue el espiritualismo el que constituye el elemento clave para salir del materialismo que, metaforizado por el personaje Calibán, expresaba el naciente imperialismo norteamericano.

En este contexto, el espiritualismo se conjuga con un idealismo que se remonta a los valores espirituales alejados del positivismo y el materialismo. La alusión en El Ariel a las ideas-fuerzas ${ }^{14}$ de Alfred Fouillé

14. Alfred Jules Émile Fouillée desarrolla el concepto de idées forces en tres obras: $L$ 'Évolutionnisme des idées-forces (1890), La Psychologie des idées-forces (1893) y La Morale des idées-forces (1908). Este concepto supone que el espíritu es la causa eficiente de la propensión de las ideas a realizarse por una acción consiente. Las extensiones éticas y sociológicas de esta 
en tanto concepto que integra elementos antagónicos ostenta una fuerte impronta práctica. Este último funciona como estrategia de acción ante la lectura de la modernidad como originadora de una crisis, que solo una moralidad fuerte, llevada a cabo por una élite del mérito, puede superar.

En Perú el arielismo se encuentra ligado a un creciente espiritualismo. Entre sus partidarios más importantes se encuentran, Francisco y Ventura García Calderón, José de la Riva Agüero y Víctor Andrés Belaúnde. Todos ellos intentan consolidar un proceso de modernización a partir de reflexiones y de análisis sistemáticos. El impacto que tienen sobre el campo intelectual es crucial, tanto para sus seguidores como para sus adversarios, ya que instituyen un modo de pensar la identidad nacional, uno de los temas desarrollados en El Ariely, por consiguiente, el lugar del indio y el del Perú en el continente americano. De acuerdo con Beigel, ${ }^{15}$ esta denominada nueva generación peruana, se adhiere a una concepción idealista de la oligarquía pero también se posiciona contra la caída de los valores de la clase dirigente. Se trata de una suerte de romanticismo que se conjuga con el espíritu de la reforma universitaria en Perú y todo el continente americano.

Asimismo, la nueva generación contiene una gran variedad de formas de protesta, desde las más moderadas, restringidas al ámbito institucional y universitario, hasta las más radicales. Beigel observa que esta generación concentra la transición

teoría intentaban resolver la antinomia de la libertad, más allá de los aspectos físicos y psicológicos individuales.

15. Beigel, F. (2006) La epopeya de una generación y una revista, Buenos Aires, Biblos. entre el modernismo y la vanguardia. Se trata del paso del espiritualismo arielista al marxismo romántico. En dicha transición se presentan disputas que permiten la emergencia de figuras como Mariátegui, quien intenta radicalizar el proceso de transición generando, como sostiene Castilla ${ }^{16}$, el paso del ideal arielista al mito soreliano.

El concepto de mito, en un sentido político, es introducido por Sorel a principios del siglo XX, en su célebre obra Reflexiones sobre la violencia. Sin embargo, diferentes exégesis sostienen que dicho concepto deviene en un problema por diferentes motivos. Entre ellos porque, como señala Tiziano Bonazzi ${ }^{17}$, no fija una relación con la mitología, por distinguirlo del concepto de ideología y, finalmente, porque se encuentra en el centro de la polémica entre racionalismo e irracionalismo. Según María José Cisneros, para el liberalismo y el marxismo, de raigambre racionalista, el concepto de mito connota fenómenos de irracionalidad que desvían y enmascaran el verdadero sentido de la política ${ }^{18}$. De allí que no lo entienden como fenómeno político.

Sorel y más tarde Mariátegui y Gramsci, rompen con esta valoración negativa ubicándose en una comprensión del mito político más próxima a la praxis que a la especulación pura y esencialista de la política. Para ellos el mito es un elemento central en la lucha política. Ya en Reflexio-

16. Castilla, M. (2012) Arielismo, mito y marxismo, La Plata: Memoria Académica de la UNLP.

17. Bonazzi, T. (1995) Mito político, Bobbio, N. Diccionario de Política, México: Siglo XXI.

18. Cisneros, M. J. (2012) De la crítica al mito político al mito político como crítica. En Fragmentos de filosofia, n. 10, pp. 53-67. 
nes sobre la violencia (1906), Sorel define a la huelga general como mito, es decir,

Un conjunto de imágenes capaces de evocar, en conjunto y por mera intuición, antes de cualquier análisis reflexivo, la masa de los sentimientos que corresponden a las diversas manifestaciones de la guerra entablada por el socialismo contra la sociedad moderna. ${ }^{19}$

Así, el mito funciona como "reforma de la voluntad" mueve inmediatamente a la acción. Este anclaje en la "voluntad" le permite al filósofo francés cuestionar las concepciones racionalistas y deterministas de la historia exaltando el papel de lo subjetivo del relato histórico, entendido como el resultado de una voluntad colectiva, capaz de intervenir violentamente en la sociedad para impedir su decadencia. Es decir, la instauración de un régimen democrático parlamentario que busca la paz y el orden social mediante el consenso entre las clases.

De allí su insistencia por reactivar la lucha de clases a través del mito de la "huelga general". Se trata de una idea que da fuerza vital al proletariado. Al mismo tiempo, promueve la violencia proletaria y sostiene que las tendencias creativas de una clase conducen a la reforma de la voluntad, que no puede consolidarse si se la somete a análisis crítico racional.

Es posible decir que el mito brinda una nueva visión del mundo, como también un estado anímico que lo lleva a la acción reactivando la lucha de clases. Entonces, la potencia del mito se encuentra es su negatividad, ya que parte de la evidencia de los conflictos existentes entre las clases llevando a la lucha organizada. En

19. Sorel, G. (2005) Reflexiones sobre la violencia, Madrid, Alianza p. 181. otras palabras, los mitos funcionan como praxis de continua resistencia.

El proyecto político de Mariátegui conjuga la recepción de Marx y la de Sorel. Mientras la primera le permite pensar las condiciones generales de una teoría crítica, la segunda le posibilita, en cambio, suturar esa teoría general con las condiciones de su contexto particular. En este sentido, ambas recepciones le ayudan a configurar una praxis política creativa, que comprende las peculiaridades del contexto peruano.

De allí que Mariátegui adapte el mito político, en tanto creación colectiva, que motoriza la historia, a la situación nacional. La mediación soreliana activa en él, igual que en Gramsci, una concepción heterodoxa del marxismo que se aleja del historicismo, del evolucionismo y de todo determinismo. De acuerdo con el filósofo peruano,

Lo que más neta y claramente diferencia en esta época a la burguesía y al proletariado es el mito. La burguesía no tiene ya mito alguno. Se ha vuelto incrédula, escéptica, nihilista. El mito liberal renacentista ha envejecido demasiado. El proletariado tiene un mito: la revolución social. Hacia ese mito se mueve con una fe vehemente y activa. La burguesía niega; el proletariado afirma. ${ }^{20}$

Cabe señalar que el concepto de mito, desarrollado por Sorel, se nutre de elementos tomados del vitalismo de Bergson, pero también de nociones del pragmatismo, para dar nuevo impulso al pensamiento socialista. Si se piensa que desde fines del Siglo XIX, Bergson y William James comienzan a organizar un proyecto de reacción positivista desde los centros cul-

20. Mariátegui, J. C. (1972) El alma matinal $y$ otras estaciones del hombre de hoy, Lima, Amauta, p. 27. 
turales del mundo, como Estados Unidos y París es posible entonces pensar que el mito soreliano es la expresión política de una concepción antropológica, que toma como suya la consigna vitalista y pragmática, es decir, desarrollar una crítica al aparato epistemológico positivista resignificando un perfil antropológico emotivo más que racional. De allí que critique las perspectivas marxistas de fuerte raíz determinista sosteniendo,

Otra actitud frecuente de los intelectuales que se entretienen en roer la bibliografía marxista, es la de exagerar interesadamente el determinismo de Marx y su escuela con el objeto de declararlos, también desde este punto de vista, un producto de la mentalidad mecanicista del siglo XIX, incompatible con la concepción heroica, voluntarista de la vida, a que se inclina el mundo moderno, después de la Guerra. ${ }^{21}$

En ese sentido, la teoría de los mitos revolucionarios, se aproxima a la experiencia de los movimientos religiosos. Desde allí se establece la base para una filosofía de la revolución.

Ahora bien, Mariátegui se posiciona contra el positivismo y el historicismo pero eso no significa que su filosofía devenga en un irracionalismo. Combate el intelectualismo porque lo considera una forma sesgada de comprender la condición humana, pero también porque lo interpreta como perjudicial a la hora de entender la política. En este punto, es necesario aclarar aquellos momentos en que Mariátegui se distancia de Sorel. El Amauta no considera que la violencia desatada por el mito

21. Mariátegui, J. C. (2010) "El determinismo marxista" en Mariátegui: política revolucionaria. Contribución a la crítica socialista. Defensa del marxismo y otros escritos, Caracas, Fundación el perro y la rana, p. 31. político debe sobreponerse sobre todo producto racional ya sea una mediación, un proyecto o un programa de acción.

El estado de ánimo épico, evocado por el mito soreliano, parece el advenimiento del fin respecto del cual Mariátegui logra diferenciarse tomando con cautela los enunciados más pesimistas que se vuelcan sobre la premisa de la destrucción de todo lo dado. Su retórica, en cambio, consiste en la plasmación de un proyecto de nación que, como lo observa Juan Ignacio Garrido, se consolida bajo la consigna, "Peruanizar el Perú"22.

\section{La concepción antropológica de Mariátegui y su proximidad con Nietzsche y Bergson}

A lo largo de la producción filosófica de Mariátegui, la relación entre el mito y la vida del hombre se profundizan, sobre todo con una fuerte impronta nietzscheana y bergsoniana. Algunos trabajos abordan la cuestión de estas recepciones. Hugo Neira ${ }^{23}$ y Aníbal Quijano ${ }^{24}$ sostienen que el pensamiento del filósofo peruano tiene una clara impronta nietzscheana, un estilo común, que se evidencia sobre todo

22. Véase Garrido, J. I. (2015) "Mariátegui, Sorel y los rastros de una polémica revolucionaria" en Herramienta debate y crítica marxista. Disponible en: http://www.herramienta.com.ar/foros-ydebates/coloquios-y-seminarios?page $=3$.

23. Véase Neira, H. (1986) "El pensamiento de José Carlos Mariátegui: Los mariateguismo", Socialismo y participación, vol. 23. pp. 55-76.

24. Véase Quijano, A. "El marxismo en Mariátegui: una propuesta de racionalidad alternativa", Sobrevilla, D. (1995) El marxismo de José Carlos Mariátegui, Lima, Amauta. 
en su fuerza crítica, y en la relación que establece entre pensamiento y vida, como también en el vínculo entre la ética y el conocimiento. Asimismo, Ofelia Schutte, en "Nietzsche, Mariategui and Socialism: a Case of Nietzschean Marxism" in Perú?", ubica la recepción mariateguiana de Nietzsche en un mismo movimiento con la apropiación que efectúa el socialismo alemán y los sectores progresistas antes de la Primera Guerra Mundial en Alemania y de la apropiación que hacen de él los totalitarismos.

Al igual que Nietzsche, el filósofo peruano se autocomprende como intelectual que busca la relación entre su vida y su pensamiento. El itinerario intelectual de Mariátegui, su aprecio por los viajes, por el mundo artístico y su impulso vital simpatizan con la filosofía nietzscheana. En otras palabras, Mariátegui considera sus vivencias como herramientas que lo llevan a constituir un compromiso social del que se desprende su reflexión. En este sentido expresa, "Mi pensamiento y mi vida constituyen una sola cosa, un único proceso. Y si algún mérito espero y reclamo que me sea reconocido es el de -también conforme a un principio de Nietzsche- meter toda mi sangre en mis ideas". ${ }^{25}$

La filosofía de Nietzsche da la posibilidad a Mariátegui de edificar un estereotipo antropológico fuerte, creador, apasionado y práctico. Es decir, capaz de apropiarse de las contingencias para fortalecerse. De allí que exprese,

Pero el hombre, como la filosofía lo define, es un animal metafísico. No vive fecundamente sin una concepción metafísica de la vida. El mito mueve al hombre en la histo-

25. Mariátegui, J. C. (2007) Siete ensayos de interpretación de la realidad peruana, Caracas, Biblioteca Ayacucho, p.5. ria. Sin un mito la existencia del hombre no tiene ningún sentido histórico. La historia la hacen los hombres poseídos e iluminados por una creencia superior, por una esperanza super-humana; los demás hombres son el coro anónimo del drama. ${ }^{26}$

En este pasaje resuena sin duda la temprana obra de Nietzsche, es decir, El nacimiento de la tragedia en el espíritu de la música (1872) donde se instalan las bases de su crítica filosófica a la lectura del mundo antiguo recuperando la tragedia griega en su complejidad como síntesis de dos instintos artísticos, es decir, el apolíneo y el dionisíaco. Sin embargo, esta no es la única obra que se presenta en el anterior pasaje de El alma matinal, sino también una obra escrita casi diez años después, es decir, Así habló Zaratustra, momento en el cual Nietzsche comienza un proyecto filosófico más consolidado.

Ahora bien, las lecturas nietzscheanas pueden entenderse en dos niveles, por un lado, la identificación de Mariátegui con Zaratustra, es decir, el sabio solitario, que tras su proceso de formación en Europa necesita compartir su conocimiento y, por otro lado, la apropiación del mito del superhombre, que el personaje de Nietzsche evoca, a saber, se trata del mito que pone al hombre en acción, olvidando el lugar pasivo en que se encuentra en otras religiones oficiales. Ya en "El hombre y el mito", publicado primero en el Mundial y luego en El alma matinal y otras estaciones del hombre de hoy, Mariátegui observa que la burguesía carece ya de mito pues los principios de libertad, democracia y paz se sacrifican por intereses personales en la conferencia de Versalles. No obstante, la guerra demuestra

26. Mariátegui, J. C. (1950) El alma matinal y tras estaciones del hombre de hoy, Lima, Amauta, p. 19. 
la fuerza del mito. Es posible pensar que al igual que Nietzsche retoma a la retórica de las religiones en defensa de principios humanos, el Amauta también asume dicha retórica para aplicarla a su propio contexto político, en otras palabras, para estimular el mito revolucionario en Perú.

Paralelamente encontramos que las metáforas nietzscheanas pueden haber alentado la imaginación del filósofo peruano, si se piensa que construye un modelo antropológico volcado sobre la tierra, es decir, sobre el mundo sensible en el marco de su proyecto de inversión de los valores instaurados por la metafísica occidental. De modo que expresa,

¡Mirad, yo os enseño el superhombre! El superhombre es el sentido de la tierra. Diga vuestra voluntad: isea el superhombre el sentido de la tierra! ¡Yo os conjuro, hermanos míos, permaneced fieles a la tierra y no creáis a quienes os hablan de esperanzas sobreterrenales! Son envenenadores, lo sepan o no. ${ }^{27}$

La enunciación de la tierra, como objetivo de la acción práctica, edifica un sujeto portador de la voluntad de poder, en tanto impulso vital e irracional hacia la supervivencia, pero además evoca una fuerza retórica, que busca conmover a las masas. Mariátegui se propia de esta suerte de vuelta del cielo a la tierra, que propone Nietzsche, agregándole sus lecturas marxistas, con el propósito de dotarla de sentido político. De manera que los principios ya no son divinos, sino humanos y sociales. En sus palabras, "Cada palabra, cada acto del marxismo tiene un acento de fe, de voluntad, de convicción heroica y creadora, cuyo impulso sería absurdo

27. Nietzsche, F. (1997) Así habló Zaratustra, un libro para todos y para nadie, Madrid, Alianza Editorial, p. 36. buscar en un mediocre y pasivo sentimiento determinista". ${ }^{28}$

Así, la instrumentalización mariateguiana de Nietzsche no sólo resulta efectiva para la praxis, sino que además tiene un fuerte componente poético. Esto nos lleva sin duda a otro punto central en Mariátegui, es decir, su condición de vanguardista artístico. El Amauta se nutre de una serie de imágenes instaladas por Nietzsche, como la del poeta, el filósofo pájaro y el mesías Zaratustra, convirtiéndolas en consignas políticas pues llevan a la acción práctica.

Es claro que el análisis en torno a este perfil antropológico nietzscheano retoma la estrategia política soreliana del mito, entendido como salida de la decaden$\mathrm{cia}^{29}$. El pensador peruano observa que la salida a la situación de Perú, oprimido por un feudalismo decadente como el gamonalismo, tiene esta doble dimensión, el componente creador, que ostenta una clara impronta nietzscheana y bergsoniana y, al mismo tiempo, el elemento violento que activa el mito político.

Entonces, las recepciones filosóficas de Mariátegui tienen como objetivo, entre otros, crear un hombre nuevo, creativo y práctico, es decir, portador de una fe combativa. En este sentido, resulta novedoso al plantear una reivindicación de la fe como catalizadora de la fuerza de los revolucionarios. Para el filósofo peruano dicha potencia no está en la ciencia, sino

28. Mariátegui, J. C. (1976) "Defensa del marxismo" en Mariátegui: política revolucionaria. Contribución a la crítica socialista. Defensa del marxismo y otros escritos, óp. cit. p. 68.

29. Mariátegui retoma el concepto de decadencia como lo entiende Oswald Spengler en su célebre libro La decadencia de Occidente (1922), entendida como la declinación de la democracia liberal y de la cultura occidental. 
en la pasión, en la voluntad revolucionaria. En otras palabras, se trata de una fuerza mística y espiritual.

Desde este enfoque, los intelectuales deben escribir la acción revolucionaria que parte de una creencia. En este punto, Mariátegui intenta demostrar que el impulso vital del hombre responde a todas las interrogaciones de la vida, antes que a la investigación filosófica. La función de la filosofía, en cambio, es defender la idea de verdades relativas, pero promover que el hombre viva como si éstas fuesen absolutas. De allí que el proletariado no es negación sino afirmación creadora.

Para Mariátegui las búsquedas del pesimismo de la realidad y del optimismo del ideal conjugan la razón con el mito, las leyes objetivas de la historia con el papel de la pasión colectiva. Luego el hombre no solo es capaz de reflexionar y analizar, sino también de sentir y de moverse de acuerdo con sus pasiones. De hecho se constituye a sí mismo por su sociabilidad con los otros. De modo que, el mito político religa a los individuos aislados con imágenes intensas.

Sin duda el pensamiento de Mariátegui recibe el impacto del boom bergsoniano en América Latina. Ya Oscar Terán lo considera un lector radical de Bergson en sus obras Discutir Mariátegui (1985) e Historia de las ideas en Argentina (2008). En estas ocasiones evidencia que, a diferencia de Alejandro Korn, quien retoma el bergsonismo desde una lectura moderada, el cordobés Saúl Taborda y Mariátegui acceden al bergsonismo de un modo extremista, por medio del anarco-sindicalismo de Sorel.

El maestro de L' École de France le otorga herramientas teóricas para pensar la situación real peruana proponiendo una ontología del tiempo donde el pasado se reactualiza en el presente por medio de la memoria. Esta estrategia es recuperada por el pensador peruano cuando vuelve, en Siete ensayos sobre la realidad peruana, al pasado indígena, para sostener que el sujeto político de Perú es el indio. Esto desquicia al marxismo ortodoxo etapista que, en cambio, sostiene que no hay revolución feudal, sino por el contrario es necesario esperar al ascenso de la burguesía. Mariátegui no puede sostener esa espera al advenimiento de la industrialización en Perú. De modo que vuelve al pasado con el fin de mostrar las transformaciones sociohistóricas de su propio contexto. En este punto, la herramienta para recuperar el pasado se encuentra en el mito. Este último, como sostiene Terán, relata una y otra vez el presente y funciona como instrumento capaz de interpelar al gamonalismo ${ }^{30}$. Esta recuperación del pasado, le permite reivindicar el concepto de comunidad indígena del que usufructuaron los colonialismos para autosatisfacerse. De esta forma, Mariátegui busca reapropiarse de este comunismo indígena, propio de la tradición andina, como punto de partida de una reorganización socialista.

Sin embargo, el Amauta se aparta del bergsonismo en sus observaciones negativas respecto de la materia, en tanto elemento retardatario de la evolución espiritual. Nuevamente, las lecturas de Marx emergen haciendo notar que las condiciones para efectivizar la libertad se encuentran en la realidad económica de su país. El espiritualismo funciona a la

30. Véase Terán, O. (1996) Mariátegui: el modernismo revolucionario en ocasión del cincuenta aniversario de la muerte del pensador peruano, Celehis, Revista del Centro de Letras Hispanoamericanas, vol. $1, \mathrm{n}^{\circ} 6,7$ y 8 . 
hora de despojar lecturas demasiado ortodoxas y sobre todo deterministas de Marx, pero no puede olvidar el dato económico entendido como factor estructurante de la sociedad. Además, la vuelta al pasado, a través del mito, toma en cuenta un factor no considerado por Bergson en su ontología, es decir, el futuro. Mariátegui organiza una recuperación de la tradición indígena que le permite tomar una actitud propositiva, esto es, la transformación social.

En síntesis, el pensador peruano, por medio de una recepción creativa de Nietzsche y Bergson, construye una concepción antropológica ligada a la idea de movimiento. Así, consolida una perspectiva que vincula lo novedoso y lo desconocido, condensado en la figura de hombre aventurero, lanzado a la búsqueda como objetivo en sí, pero también a la de un hombre creador y por ello fundador de nuevos mundos. En otras palabras, Mariátegui se nutre más que de conceptos, de imágenes, como las de hombre ligado a su impulso vital y asociado al concepto de libertad, que tiene como horizonte teórico la filosofía Nietzsche y de Bergson.

De acuerdo con Ibáñez, esta idea de libertad le permite a Mariátegui orientar su pensamiento lejos del marxismo ortodoxo $y$, a la vez, le da la oportunidad de combinar la cuestión nacional y el marxismo con el indigenismo, el socialismo moderno con la tradición andina y, finalmente, la fe con el pensamiento y la cultura contemporánea ${ }^{31}$. Desde este posicionamiento teórico articula una suerte de marxismo creador, ya que su obra se remonta a un concepto de historia como producto de la invención de los hombres. Su carácter

31. Ibáñez, A. (2001) "Mariátegui: un marxista nietzscheano", En Espiral. Estudios sobre Estado y Sociedad, vol. 7, pp. 11-24. antidogmático, crítico y creador combate las doctrinas positivistas o deterministas. Con lo cual efectúa una estetización de la política y encuentra en el socialismo la religión de su tiempo rechazando un evolucionismo histórico pasivo y resignado. En esta perspectiva, que postula una voluntad creadora en la historia, también presenta una función ética del socialismo que eleva a los trabajadores en lucha, según la expresión de Sorel, a una "moral de productores".

\section{Conclusiones}

A lo largo del presente trabajo intentamos evidenciar los elementos que permitieron a Mariátegui articular una visión propia del marxismo. Con tal propósito organizamos una reconstrucción resumida de su contexto histórico, entendido como elemento determinante en el pensamiento de un autor comprometido con su realidad concreta. Tanto como espectador de la escena política internacional y de los debates que allí se desarrollaron, como también de las preocupaciones por dar respuestas a las problemáticas nacionales, Mariátegui presenta una visión del socialismo con características innovadoras al establecer al indio como sujeto político.

En este contexto, se articulan un sistema de recepciones teóricas que van desde las tendencias latinoamericanas, vinculadas al modernismo fundado por El Ariel de Rodó, hasta elaboraciones de vanguardia, relacionadas a un marxismo mediado por la interpretación de Sorel.

Tanto los elementos teóricos, que marcan la situación latinoamericana, como los tomados del marxismo heterodoxo conjugan un rechazo contundente a la visión cientificista, determinista, intelectualista, 
evolucionista y mecanicista, que organiza el discurso democrático liberal de la burguesía, y que se orienta hacia una política conservadora fundada en la base de un consenso ficticio.

La elección del mito como herramienta de combate, lo lleva a refundar el marxismo en clave idealista, proponiendo una reconciliación entre la teoría y la praxis, para dar lugar a un concepto de hombre ligado no solo a su capacidad analítica y racional, sino también vinculado, como lo propone Nietzsche y Bergson, con sus pasiones y sus emociones.

\section{Bibliografía}

Aricó, J. (1980) Mariátegui y los orígenes del marxismo latinoamericano, México, Pasado y presente.

Bajtin, M. (1990) La cultura popular en la Edad Media y en el Renacimiento: el contexto de François Rabelais, Madrid, Alianza.

Becker, Marc (1993) Mariategui and Latin American Marxist theory, Ohio, Ohio University Press.

Becker, Marc (2006) "Mariátegui, the Comintern, and the Indigenous question in Latin America", Science \& society, vol. 70, n०4, pp. 450-479

Beigel, F. (2003) El itinerario y la brújula. El vanguardismo estético político de Carlos Mariátegui.

Beigel, F. (2005) "La circulación de ideas La circulación internacional de las ideas de José Carlos Mariátegui", Prismas. Revista de historia intelectual, $n^{\circ}$ 9, pp. 7187.

Beigel, F. (2006) La epopeya de una generación y una revista, Buenos Aires, Biblos.
Bobbio, N. (1995) Diccionario de Política, México, Siglo XXI.

Castilla, M. (2012) "Arielismo, mitos y marxismo espiritualista en el pensamiento de José Carlos Mariátegui", La Plata. Disponible en:

http://www.memoria.fahce.unlp.edu.ar/ trab_eventos/ev.1778/ev.1778.pdf

Chakrabarty, Dipesh (2008) Al margen de Europa. Pensamiento poscolonial y diferencia histórica, Barcelona, Tusquets.

Cisneros, M. J. (2012) "De la crítica al mito político al mito político como crítica", Fragmentos de filosofía, vol. 10, pp. 5367.

D' Allemand, P (2016) “Todo lo humano es nuestro: una nueva mirada al legado de José Carlos Mariátegui", en Cuadernos le literatura, vol. XX, n 40, pp. 537-559.

Flores Galindo, A. (1980) La agonía de Mariátegui. La polémica con la Komintern, Lima, Centro de estudios y promoción del desarrollo.

Fouillée, A. J. É. (1890) L'Évolutionnisme des idées-forces, Paris, Alcan.

Fouillée, A. J. É. (1893) La Psychologie des idées-forces, Paris, Alcan.

Fouillée, A. J. É. (1908) La Morale des idées-forces, Paris, Alcan.

Ibáñez, A. (2001) "Mariátegui: un marxista nietzscheano", Espiral, Estudios sobre Estado y Sociedad, vol. 8, pp. 11-24.

Löwy, Michael y Ortega Breña, M. (2008) "Communism and Religion, Mariátegui's revolutionary mysticism", Latin American Perspectives, vol. 35, n² 2.

Mariátegui, J. C. (1970) Peruanicemos al Perú, Lima, Amauta.

Mariátegui, J. C. (1950) El alma matinal y otras estaciones del hombre de hoy, Lima, Amauta.

Mariátegui, J. C. (1974) La novela y la vida, Lima, Amauta. 
Mariátegui, J. C. (2007) Siete ensayos de interpretación de la realidad peruana, Caracas, Biblioteca Ayacucho.

Mariátegui, J. C. (2010) Defensa del marxismo y otros escritos, Caracas, Fundación el perro y la rana.

Neira, H. (1985) El pensamiento de José Carlos Mariátegui: 'Los mariateguismos'. En Socialismo y participación, vol. 23. p. 55-76.

Paris, R. (1981) La formación ideológica de José Carlos Mariátegui, México DF: Siglo XXI (Cuadernos de Pasado y Presente, 92).

Quintanilla, P. (2004) “Del espejo al caleidoscopio: aparición y desarrollo de la filosofía en Perú", Areté. Revista de Filosofía, vol. 16, pp. 43-79.

Quijano, A. (1981) Introducción a Mariátegui, México, Ediciones Era.

Quijano, A. (1995) "El marxismo en Mariátegui: una propuesta de racionalidad alternativa", Sobrevilla, D. (Comp.)
El marxismo de José Carlos Mariátegui, Lima, Amauta.

Rodó, J. E. (1996) El Ariel, Buenos Aires, Losada.

Sorel, G. (2005) Reflexiones sobre la violencia, Madrid, Alianza.

Spengler, O. (2011) La decadencia de Occidente, Barcelona, Austral.

Tarcus, H. (2002) Mariátegui en Argentina: Las políticas culturales de Samuel Glusberg, Buenos Aires, Ediciones El cielo por asalto.

Terán, O. (1985); Discutir Mariátegui. Puebla: ICUAP.

Terán, O. (2008) "Amauta: Vanguardia y Revolución", Prismas, vol. 12, pp. 173198.

Terán, O. (1996) "Mariátegui: el modernismo revolucionario en ocasión del cincuenta aniversario de la muerte del pensador peruano", Celehis, Revista del Centro de Letras Hispanoamericanas, vol. $1, n^{\circ} 6,7$ y 8 . 